\title{
Banishment and the pre-history of legitimate expulsion power ${ }^{1}$
}

\section{Matthew J. Gibney}

In the introduction of a recent work on the denationalization of terrorists across the West, the legal scholar Audrey Macklin announced that "after decades in exile, banishment is back" (Macklin 2015). Over the last decade, as new laws allowing individuals to be stripped of citizenship have sprung up in states including the UK, Canada, Australia, Finland and the Netherlands, many others have also analogised denationalization to this medieval practice (Sassen 2015; Lenard 2019; Pillai \& Williams 2017). By allowing states to deport their own citizens or, if present overseas, to prevent their return, denationalization, like banishment, enables states effectively to disown their members (Macklin 2015; Gibney 2013a; Mantu 2015).

Scholars have recently given a great deal of attention to the question of why citizen banishment qua denationalization has returned to our political lexicon. Citizen expulsion has important implications for ideas of equal citizenship, democracy, and norms relating to statelessness (Macklin 2015; Gibney 2013a; Lenard 2018; Fargues 2017). What scholars have generally ignored, however, is why banishment ever went away in the first place.

Before the twentieth century, the expulsion of individual offenders, typically citizens or settled residents, from the city, province, state, or even the empire, as a punishment, was, in a range of different forms, in everyday use across Europe. Its ubiquity and frequency reflected a widespread and deeply ingrained view that membership and continued presence in political society was contingent upon behaviour that adhered to the law and dominant societal norms. Those who violated key norms could rightfully be banished from the community. As late as the mid nineteenth century, many countries, including Britain, France and Germany, were still expelling convicts from their territory as a punishment.

\footnotetext{
${ }^{1}$ I am grateful to many people for helpful advice on this piece over a number of years. I would particularly like to thank, in no specific order, Bridget Anderson, Tom Scott-Smith, Alexander Betts, Rainer Baubock, Rutger Birnie, Guy Goodwin-Gill, Benjamin Gray, Diletta Lauro, Audrey Macklin, and Chimene Bateman. The anonymous reviewers for this journal also provided extremely helpful comments and saved me from several errors.
} 
The acceptability of expulsion as a punishment was endorsed not only by ancient and medieval thinkers; it was also defended by many famous Enlightenment theorists. Most notably, it was on display in Cesar Beccaria's famous reformist work of criminal justice of 1764, Of Crimes and Punishments. While Beccaria's work is renowned because of its critique of the state's right to execute--to bring about bodily death-his embrace of the right to inflict civic death is often overlooked. In Of Crimes, Beccaria unambiguously pronounces: "he who disturbs the public tranquillity... who does not obey the laws, who violates the conditions under which men mutually support and defend each other, ought to be excluded from society, that is, banished" $(1995,56)$.

My aim in this piece is to explain why the practice of banishment disappeared from modern societies and, in so doing, to understand better the character of its contemporary "revival". A wealth of historical work on practice of banishment has appeared in recent decades (e.g, Allen 2000; Dorin 2015; Coy 2008; Evans 1998). But these studies tend to focus on the use of the practice during specific historical periods, often in localised contexts. ${ }^{2}$ Here, I use this diverse scholarship to assemble a unique picture of the development of banishment over the longue durée. I suggest that while banishment proved compatible with a range of ways of conceptualising citizenship and societal purposes across the ancient, medieval and early modern worlds, the rise of the territorial state and, in particular, nationalised conceptions of membership in the nineteenth century undermined this punishment, both normatively and practically. Modern denationalization, I argue, revives citizen banishment but only in a highly modified and constrained form that, paradoxically, denies to the state the formal right to expel its own members as a punishment.

The discussion that follows is divided into six sections. In the first, I consider the use of banishment in ancient Greece and republican and imperial Rome, highlighting in particular in the way the punishment was conceptualised primarily as a citizen privilege. In Section II, I consider how the medieval world carried on the use of banishment under the influence of a range of traditions, including Roman and customary law, but also drawing upon religious justifications in the practice. In Section III, I illustrate how, while traditional forms of banishment remained, the practice was increasing enlisted by the early modern state to serve the purpose of colonial expansion and captive labour, exemplified in convict transportation. I

\footnotetext{
${ }^{2}$ The closest piece to my own (in English) is an excellent discussion of the history of expulsion power in its many forms by William Walters (2002). Walters' piece discusses banishment but only as one amongst a range of collective expulsion practices.
} 
turn in Section IV to consider the attitudes of early liberal theorists to banishment, illustrating the compatibility of the practice with a conception of the state as a social contract. In the final substantive section, I consider how the practice of banishment - in its various incarnationsbegan to be seen as both impractical and normatively unacceptable from the late $18^{\text {th }}$ century due to increasing state centralisation, the rise and spread of the national ideal, and new ideas about the role of reform in punishment. I conclude by considering the extent to which modern banishment, of the type evident in denationalization and deportation practices, is similar to its historical antecedents.

My efforts to trace this history require that I specify what is meant by banishment in advance. This is no easy task because, as I will show, the practice took a number of forms in different historical contexts. However, here I define banishment as the formal punishment of expulsion of an individual from the territorial boundaries of a political community leading to the loss of rights and privileges associated with membership. In its archetypal form banishment was a symbolic and legal act of communal disownment, though as we shall see, the punishment often departed in practice from this archetypal form for the sake of mercy, reform, and exploitation. My definition of banishment, which focusses on formal, regular, and individualised practices, has the advantage of shedding light on the historical development of what one might call the legitimate expulsion powers of political communities. Historically, political communities have expelled unwanted and undesirable individuals and groups in a variety of different ways. Mass departure has been fomented directly by acts of persecution and dispossession and indirectly by authorities failing to protect individuals and groups from local violence, such as pogroms and conflict. Yet these kinds of occurrences, important as they are, shed little light on the development of legitimate expulsion power, largely because they have typically been sporadic episodes, occurring outside the usual operation of law. By contrast, banishment was typically an official punishment, codified in law and part of a range of sentences (including fines, corporeal punishments, imprisonment and death) handed down by courts and other sentencing bodies.

Banishment thus offers insights into how communities conceptualised the character and limits of their right to expel in relation to particular individuals under quotidian circumstances. The value of this focus is obvious if one notes the strong affinities between the practice and contemporary deportation and denationalization power. It is perhaps unsurprising given that our main word for legal expulsion springs from a Roman banishment practice, deportatio. 


\section{Banishment in Ancient Greece and Republic and Imperial Rome}

Virtually all human societies have used banishment — in some shape or form — to ensure social order and civic peace and to punish miscreants. The punishment of expulsion serves three major roles. It removes the offender from public view and thus decreases the likelihood of a spiral of revenge and retaliation that would upset the civil peace from those who have been harmed by unlawful acts. Banishment also incapacitates the offender by placing her outside the boundaries of community, protecting other community members from those who would harm them. Finally, the punishment promises to purify the community. By purging society of failed members, banishment demonstrates the worth of membership and affirms the symbolic boundaries of community.

Yet other punishments, like imprisonment and execution, may serve these goals just as well. Why does any particular society choose banishment? To answer this question one must look at how, where and why banishment was used in practice. While banishment was widely practiced across a range of ancient societies and civilizations, including the Chinese and the Egyptian, my point of departure here will be ancient Athens and republican and imperial Rome. These societies are of particular relevance because of the role they played in influencing the spread of the practice across Europe: the first as a model; the latter because of its legacy of law, expanded through the reach of Empire.

Banishment took on a range of different forms in ancient Greece and republican Rome. One was as a type of self-exile which enabled the accused or convicted individual to escape other, more severe (or humiliating) punishments. In ancient Athens, banishment as self-exile was a common alternative to death penalty, particularly for citizens. Convicted murderers awaiting punishment and individuals on trial for capital crimes were actually expected to banish themselves. There was even a conventional time for doing so: after the first speech at trial (Allen 2000, 202). Famously, fleeing was the expectation that Socrates frustrated by taking his punishment and drinking the hemlock. This form of punishment might appear an evasion of punishment rather than a punishment itself. Yet any individual who fled in such a matter could not return to the city and could be punished with death for doing so. What looks like an act of individual choice becomes, under law, an act of forced exile. Self-banishment of this type was appealing in democratic Athens because it took the miscreant away from public view and thus prevented further violence. As Danielle Allen observes, in contrast to other punishments that enabled the city to memorialise wrongdoing, the aim of banishment was to enable communal 
"forgetting" by requiring that "the citizen disappear from the sight of the citizenry" (Allen 2000, 203).

A remarkably similar system operated in Rome during the republican period. Fleeing into exile in the face of a capital sentence was considered a patrician privilege. Upon departure individuals were subject to the interdictio aquae et ignis, a kind of "conditional death sentence" (Bauman 2002, 20) whereby the individual would be "cut off from fire and water", "symbol of civic communion", and thus denied the necessities of life. The punishment, used for criminal offences, such as arson, poisoning and treason, began as custom and developed into law, carried with it a loss of status and citizenship (Peck 1898, 653-654; Grebe 2010). It meant that the individual was denied the protection of the law and could be killed by any citizen without commission of a crime. The origins of the interdictio lay in the religious punishment of sacratio through which "a wrongdoer was expelled from his in order to leave him to the vengeance of the deity whose sacred laws he had violated." (Grebe 2010, 503). Self-banishment from the community thus offered a way of purifying the community and restoring its position in the eyes of the gods (Grebe 2010).

Less ambiguously, banishment also took the form of a codified punishment in ancient Athens. Athenian law specified banishment as a fixed punishment for crimes including unintentional homicide and attempted tyranny (Forsdyke 2009, 178). For other crimes, banishment was one alternative amongst a range of punishments that included fines and death and period in the stocks (Forsdyke 2009, 179). Imprisonment was also used in Athens but it was not a mandated penalty (Allen 2000). Sentences of banishment could handed down by various decision-making bodies populated by citizens including councils, juries, and assemblies (Forsdyke 2009) After the founding of democracy trials for major crimes, including tyranny, took place before the Council of the Five Hundred (constituted by citizens) in the $5^{\text {th }}$ century BCE (Forsydke 2009). The punishment varied in its severity. It could be ordered for a specified period or permanently, as was the case with attempted tyranny. Banishment could also be "amplified with the confiscation of property and/or the razing of the convict's house" (Allen 2003, 16).

Another symbolically important, if little used, practice in ancient Athens was ostracism. In the fifth century, BCE, the Athenian assembly had the power to expel any citizen from Athens for ten years. Held annually, the expulsion process enabled the assembly (in principle, every citizens of Athens, of whom there might have been as many as 50,000 (Cartledge 2006)) to decide whether to hold an ostracism. If a majority voted for it, an assembly would be held 
several months later in which the candidate to be expelled (whose name would be scratched on pieces of broken pottery (ostraka) was the individual who received the most votes. That individual had to leave the city and the territory of Athens

as soon as possible, and to stay outside certain fixed geographical limits for a stretch of ten years...He was not formally deprived of his citizen status", nor was formally deprived of his property: "in fact, he might well be able to live quite comfortably on property he held outside the limits of the Athenian state. But politically, civically, he was dead, or at any rate in a state of suspended animation for the ensuing decade of his "sentence" (Cartledge 2006).

Not stemming from a legal violation, ostracism was not a punishment as such. As Cartledge notes, it is most accurately conceptualised as a kind of "reverse election" or "de-selection" (2006).

The connection between citizenship and expulsion was evident also in that in Athens banishment was used exclusively on citizens. Banishment's power lay in its loss of citizenship rights and its use on individuals with no rights to take away would have been gratuitous (Gray 2011, 568). When slaves committed crimes, their masters were fined and slaves executed or whippings and beatings ordered. Women could "lose rights to participate in religious spaces and events" but had no political rights to lose (Allen 2003, 16). In Athens, the individual needed to possess civic life to be eligible for a punishment that inflicted civic death.

In republican Rome, unlike Athens, banishment was effectively confined to self-exile (interdictio). Only under the leadership of Caesar Augustus in the early Empire did more direct varieties of banishment emerge. One of these was the punishment of relegatio, which involved expulsion from Rome for a temporary or permanent period of time. The relegatio was a sanction limited to non-capital crimes and both citizens and non-citizens could be subjected to it. Under Augustus in 18-17 BCE, it was used to punish adultery, although it was also a penalty for many other crimes. In the first century, Cassius Severus was relegated for spreading anonymous pamphlets that defamed eminent Romans. The relegatio could be ordered by provincial governors or regular judges (Robinson 2007, 81).

The relegatio was sometimes considered a relatively mild punishment, in part because it did not involve a complete loss of property or withdrawal of citizenship status and might only be temporary. Moreover, those subject to relegation were not usually removed by force and could often choose where they wanted to go. Braginton cites the following account of Agrippinus's banishment in 66AD: 
When told he had been condemned, he inquired, "To exile or death?" "To exile", was the reply. "What about my property?", he asked. When he learned that it had not been confiscated, his words were, "Well then, let us go to Aricia and take our lunch there" $(1944,394$.

This equanimous attitude was not shared by all. In exile, Cicero described himself as "routed by his tears" and "yearning for death" (Claassen 1992, 26). And the poet Ovid described his banishment to Tomis on the Black Sea in dramatic terms: "I am now enduring the extreme, thrust forth into the midst of enemies... I alone have been sent to the mouths of the sevenstreamed Hister, I am crushed beneath the Parrhasian virgin's icy pole.” (T.2, 187-190).

There was less ambiguity about the severity another form of banishment that emerged in the early Empire. Under the rule of Augustus in 2 B.C., the interdictio (right to flee exile) was replaced by deportatio, banishment not simply from Rome but to a particular place, typically an island like Sardinia, or to the outposts of empire. Like interdictio, deportatio involved a permanent loss of citizenship and property rights. According to Sarah Cohen (2008), the practice first emerged in the private household of Augustus when he expelled his daughter Julia for adultery to Pandateria, a small island off the coat of Italy. The punishment of deportatio ad insulam thereupon rippled outwards from Augustus's household to become "standard places of exile in the Principate" (Cohen 2008, 206). The punishment quickly became part of the criminal law and by CE 12 it was a formalised. From then on, "all Romans subject to aquae .. or later to deportatio were to be sent to islands" $(2008,216)$.

In the early empire, deportatio was used as a sentence for a range of offences, like murder, sexual crimes and kidnapping" and for more political offences, including lese majeste and abuse of office (Cohen 2008). It seriousness was registered in the fact that it could not "be inflicted by a provincial governor" alone but always had to be confirmed by the emperor and it was he who assigned the offender "to a specific place" (Cohen 2008).

Deportatio was a kind of capital punishment for patricians, providing an alternative to the interdictio, which it replaced. It offered an appropriate way of responding to upper class criminals because "it did not affect the body in the way death, forced labour or indeed imprisonment did" (Hillner 2013, 394). Indeed, many of the crimes for which it was a sentence were crimes that would be more likely to be committed by elite rather than lower class malefactors. In this respect the use of banishment, like other sentencing in the Roman Empire, reflected the status of offender under judgement and, in particular, the distinction between honestioires (the wealthy elite), who were seen to possess dignitas and existimatio, and humiliores (the common people). The implications of this distinction for appropriate 
punishments was made abundantly clear by the Severan period jurist Marcian when he described a change in law for murderers and poisoners: it is "customary to inflict capital

punishment unless the parties are honestiores, in which case they receive the punishments laid down by statute. It is customary for persons of inferior rank to be thrown to wild beasts, and for those of higher rank to be deported to an island" (Perkins 2013, 186)

It is evident from this brief sketch that banishment in the ancient period was complex. It varied from a simple prohibition on return (the right to flee a capital sentence), to an obligation to depart under the threat of coercion (the Roman relegatio or exile as a statutory penalty in Greece), to deportation in chains to a particular undesirable place (the use of deportation) in the Empire. These variations enabled society to adjust the severity of punishment in response to different crimes (for example, expulsion could temporary or permanent; simple expulsion or effective imprisonment on an island) and provided alternatives to harsher or more humiliating penalties (such as death or corporal punishments). As Washburn compelling notes, banishment had a "hybrid nature. It coerced even while it exercised restraint" (Washburn 2012, 16).

As significantly, banishment for the ancients was a citizen--or, more accurately, an elite-punishment par excellence. Banishment was not solely used on citizens. But its ability to serve as a moderate alternative to the harsher, undignified, bodily punishments appropriate for slaves and foreigners, made it a particularly useful as an elite sanction. Even deportatio under Empire offered the advantage of escaping something worse: the death penalty at the hands of the state. Banishment was also a distinctively citizen punishment because only citizens could truly feel its sting. The rights and privileges that the punishment of banishment existed to take awaythe right to equal standing, to vote and to serve in offices, significant property holdings, and to other key privileges — were, particularly in Greece, available only to citizens.

\section{Banishment in the Medieval Period}

Roman law transmitted by the Empire across Europe was one factor that ensured that banishment also played a central role in justice in medieval Europe. The fall of the western Roman Empire in 476, did not end banishment, it simply resulted in it being practiced on a more local scale. Indeed, long after the Empire's fall, many European cities and societies still grounded their legal sanctions on Roman practices. In the early modern period, a general criminal code, the Consitutio Criminalis Carolina (1532) based largely on Roman law, had been drawn up to provide a common standard for punishments across the Holy Roman Empire. Banishment figured prominently; usually accompanied by "flogging, pillorying, cutting off of 
fingers, and cutting out of tongue", it was the second of an ascending scale of punishments that began with flogging and ended with death (Langbein 2012, 28).

The Carolina reflected what had become customary practice across the patchwork of towns, estates, cities, and provinces that constituted medieval Europe. During the High Middle Ages banishment was a regular criminal sanction prescribed by a diverse range of judicial institutions and endorsed by the Biblical story of Adam and Eve's expulsion from the Garden of Eden. For medieval Christian communities, "history itself began with a banishment" (Dorin 2015, 4).

Recent scholars of medieval crime and justice have noted that while flogging, amputations, and hangings were sometimes ordered, fines, confiscations and particularly banishments were at least as common as a penalty for many crimes in European cities. In late medieval France, for example, as well as punishing theft, vagabondage, and murder, banishment was a penalty used for those accused of a crime who failed to present themselves before the court (Geremek 2006, 19). In 1491, the German city of Ulm embarked upon a campaign to rid itself of the "many strangers and useless people that linger here" which ultimately resulted in the banishment of more than a thousand people (Coy 2008, 1). In Cracow in the 1360s, banishment was used by the courts "for all manner of offences", with more a dozen murderers, and at least twice that number convicted of assault, banished or outlawed annually during the decade (Dean 2014, 129).

The judicial sentence of banishment usually involved something similar to the Roman relegatio: individuals were sent from the city and required not to return for a specified period. The exile was thereupon allowed to go where she wanted, or at least where she would be accepted. Banishment was not always a merciful sanction. In $14^{\text {th }}$ century Cracow, the punishment could vary from one year's exile for violence, to a hundred years for acts of violence, and perpetuity for murder (Dean 2014, 129-30). Indeed, banishment was feared as it pushed the malefactor "into destitution and banditry, cutting their contacts with family and friends and exposing them to the unpunishable violence of bandit catchers" (Dean 2014). Moreover, the punishment's use reflected a world view in which "public shaming and dramatic exclusion from the community" were considered more punitive than direct physical pain (Tarlow \& Lowman 2018).

Other forms of banishment in medieval Europe resembled the interdictio. From the twelfth century, those in England who wished to escape prosecution could, upon finding sanctuary in a consecrated place and after confessing their crime, take an oath of abjuration. This involved 
"a commitment to leave the kingdom and not return without the permission of the Crown" (Bleichmar 1999, 120). The individual was then guaranteed safe passage out the country from an assigned port. More widespread across the continent and with an even longer history was the sentence of outlawry, which was passed by courts and other juridical authorities during the medieval period. While the use of outlawry differed from place to place, in the Italian states during the renaissance period a declaration of outlawry typically mean that the absent offender lost all "civil personality and any act against him was lawful" (Wolfgang 1958, 558).

Under medieval Christendom, there was a close connection between banishment and excommunication, illustrative of the entanglement of church and state. The medieval practice of the Imperial Ban, for example, gave to the Holy Roman Emperor powers similar to those possessed by Roman leaders like Augustus, with an ecclesiastical gloss. The Ban was typically reserved for heresies or grave offences committed by the powerful or influential, such as Martin Luther's acts of defiance in 1521 and Frederick's aide to the Antipope in 1415. It entailed physical banishment of the individual from the community and the withdrawal of all civil rights. This "terrifying thunderbolt of sovereign imperial jurisdiction" (Holborn 1982, 23) while originally held by the Holy Roman Emperor was later devolved to bishops. The Ban typically followed excommunication on grounds of contumacy towards religious authority in German parts of the Holy Roman Empire. Its aim was less to punish the heretical individual than to isolate him and thereby prevent the apostate from contaminating the wider community of believers.

The attractions of banishment in medieval Europe do not seem very different from of the Greco-Roman world. The punishment offered an alternative to quick but brutal sanctions (like the stocks) and the finality of execution, though, ironically, it was often accompanied by corporeal punishments and conceptualised as a form of death (albeit a civic one). Authorities in Nuremberg during the 1500s not uncommonly spared youths and pregnant women from execution by converting their sentences to banishment (Harrington 2013). More generally, banishment was used in cases where circumstances mitigated the severity of the crime, such as unintentional homicide, or where the surprisingly high standards required for conviction could not be met but the individual was in "bad repute" (Jordan 2015). The appeal of outlawry was another matter altogether. A key advantage of this declaration was that it offered societies with weak powers of legal enforcement a way to affirm the law without actually apprehending violators of it (Sartore 2013). This became less necessary with the rise of more effective state enforcement of punishment from the 1500s. 
Who was subject to banishment was quite different in medieval societies than in the GrecoRoman world. Banishment lost its primary role as a citizen (as in Greece) or patrician (as in the Roman empire) privilege. One indication of this is that banishment in medieval societies was no longer separated from the kinds of humiliating corporeal punishments that the ancients would have deemed inappropriate for citizens or honestiories. Whipping the banished out of town was a common medieval practice and the Carolina specifically prescribed banishment in conjunction with flogging or mutilation. The expansion of banishment to cover a wide-range of different crimes and the frequency of its use in many medieval cities also suggests that the punishment was no longer the preserve of a particular class.

This does not mean that medieval Europe was egalitarian in terms of punishment. European societies, in this pre-national citizenship age, were characterised by numerous gradations of standing. The provision of civic, political and social rights varied with rank and the criteria that distinguished between members and foreigners were quite different from those that became common in the nineteenth century (Farhmeir 2000, 17). "Membership of an estate (Stand)", as Fahrmeir notes, "was more important than membership of a state; social rank was of far greater significance than geographical origin" $(2000,17)$. Civil and political rights were controlled by a range of institutions including guilds, universities, municipalities, and estates. Citizenship existed as a status but it was generally referred to membership of a city and was restricted to those inhabitants of a city with the requisite money, resources, status and occupation to gain (or to be offered) the status (Nicholas 2014).

The privileges of citizens and nobility still had influence upon the kind of sentence and individual convicted of a crime would receive. For example, citizens and aristocrats sentenced to death were entitled to be executed by the sword rather than by hanging. Beheading was preferred "as much for its connotation of honour as for its swiftness" (Harrington 2013, 62). While it seems plausible that citizens and nobles convicted of capital crimes were often banished rather than executed, this is unlikely to have been considered an entitlement.

In practice, both citizens and the low status residents of a city were often more likely to be banished than a foreigner who committed a capital crime. Harrington (2013) shows in his insightful study of crime and punishment in seventeenth century Nuremberg that to be a foreigner in an age when cities were often separated from each other by many days hard travel was immediately to be suspect. Foreigners suspected of crimes were thus less likely to be believed than citizens and other residents and they lacked allies and acquaintances who could 
plead for mitigation when they faced judgement, making the gallows more likely. The citizen or low born resident might, by contrast, escape with a whipping and banishment. The opposite could also be true. In his study of the practice of sentences of banishment meted out to usurers in late medieval Europe, Dorin (2015) shows that expulsion was used on those deemed foreign (usually Jews) with "native Christian usurers" generally escaping the punishment. This distinction, entrenched in Canon law in 1274, was one that jurists and theologians found difficult to explain (Dorin 2015). Clearly, banishment's use was still coloured by conceptions of membership.

\section{Banishment in Early Modern Europe}

Given its historical ubiquity, it is not surprising that banishment did not simply disappear with the emergence of the modern state from the 1500s. In early modern Europe, banishment remained a common secondary punishment. In France, banishment for less than nine years was one of the least severe of nine criminal punishments specified in criminal code of 1670 (Kingston 2005, 26). It was known an afflictive sanction, one which did not cause "corporal harm" but which did result in "legal infamy" (Kingston 2005, 26). In many places throughout Europe, such temporary banishment carried with it a loss of "honour or political rights" but "it did not affect property rights in any way." (Kingston 2005, 26) and could be used in response to a wide variety of offences. In seventeenth century Ulm, for example, adulterers were banished for a specified period of time, though normally only if their partner refused to take them back after their transgression (Coy 2008). In Leiden in the 1650s, a textile worker “convicted of singing scandalous songs" was banished for 12 years (Bartlett \& Cruz 2007, 179).

Banishment was often used to police violations of society's normative order, such as deviations from the moral code. In $17^{\text {th }}$ century Amsterdam, many of the large number of the city's residents banished had been convicted of sexual offences such as engaging in sodomy, concubinage, incest, or other violations of the religious order (Speirenburg 1995, 56). Foreigners were rarely banished for such crimes, in part because there was less concern about their moral welfare (Speirenburg, 1995, 56). In post-Reformation Ulm, as Jason Coy notes, the banishment of deviant, defiant and troublesome citizens was perceived to be an important step towards "a godly city" (Coy 2008, 111).

As in the medieval period, a sentence of temporary banishment often reflected official clemency or even a judgement that the offender was capable of reform. In Nuremberg of the 
1600 s, sentences that would typically result in execution were often converted to banishment when the offenders were young, pregnant, or up before the court for the first time. Temporary banishment offered the opportunity of the individual's eventual reincorporation back into society, after a cooling off period marked by exile (Margolf 2017). Banishment also continued to provide a less severe option for judges and tribunals, especially when there were doubts about an individual's guilt or death was deemed undesirable or excessive (Kingston 2005; Harrington 2013). The punishment's effects could even be mitigated after sentencing. In eighteenth century Paris, offenders sometimes argued successfully to have their expulsion delayed (Margoff 2017) so that they could get their affairs in order. It was also not uncommon for the family and friends of banished individuals to petition successfully for their return.

Return did not guarantee reintegration. Up to the $17^{\text {th }}$ century banishment was often accompanied by forms of bodily mutilation--like cutting off of tongues--that left a permanent mark upon the individual. The sixteenth century Swedish jurist, Olavus Petri, went as far as saying that this kind of physical mutilation meant that when offenders go "to other lands where no one knows them and [they] wish to reform and conduct themselves well, they are never trusted." If such mutilation was necessary, he opined, "it might have been better for ... [the banished man] to lose his life immediately (quoted in Eriksson 1976, 3).

Perpetual banishment, a modern form of deportatio, was another matter altogether. It was typically reserved for those found guilty of serious crimes that might otherwise lead to death, such as murder, sodomy, incest and was considered a capital rather than an afflictive punishment because it permanently deprived the individual of liberty or rights (Andrews 1994, 308). In France, temporary banishment excluded one only from the local jurisdiction; perpetual banishment, by contrast, typically excluded an individual from the Kingdom as a whole (Kingston 2005). A 1670 French ordinance ranked perpetual banishment the fourth harshest penalty available to the judiciary and limited its use to the Royal Courts. The punishment could be inflicted only upon men (Kingston 2005, 26).

Banishment for life was a form of civic death of great symbolic moment. The punishment was usually carried out in a highly ceremonial way that made the populace aware of the miscreant and linked his plight to death. In German cities, for example, the same bell that tolled during execution ceremonies tolled during the period which an individual was escorted from the city to begin their period of banishment (Evans 1996). In eighteenth century France, an individual facing banishment would go through a set of steps designed to publically to display and shame 
the malefactor exactly the same as one condemned to execution. This would begin with "a public reading of the sentence outside the prison door; next the individual would be loaded onto an open cart so that he was plainly visible, and a "travelling show" would thereupon begin during which the malefactor would travel through Paris, stopping to be stripped and beaten at certain town markers, before being formally escorted from the city (Friedland 2012, 95).

This ritual served the purpose of symbolizing the change from citizen to outcast. Indeed, as Friedland notes, "as odd as it may sound, permanent banishment...represented more of a definitive exclusion from society than did most punishments involving death" $(2012,99)$. Those who sentenced to death might be reincorporated into the community after death by being buried on consecrated ground, if they had confessed their crime. By contrast, "permanent banishment meant exclusion without the possibility of reconciliation" (2012, 99). Again, as had been the case in Greece and Rome, banishment's full force, then, could only be felt when it was carried out on one of one of society's own members.

But while the early modern period shared much in common with previous periods, it also presaged important changes. From around the $1600 \mathrm{~s}$, banishment appeared increasingly to offer a way of ridding communities of unwanted itinerants, like vagrants and beggars, who were costly and annoying to host because of their dependence upon the community for support. Banishment in this form was an early method of border control that reinforced distinctions between members and strangers based on place of origin. Rather than a mechanism used to convey social stigma and shame, this use of banishment presaged contemporary migration controls, albeit at the level of the city or town.

The movement of impoverished people was a significant problem in early modern Europe. Population growth and low agricultural productivity combined to create large numbers unemployed workers unable to earn the necessary means to survive. These "masterless men" (Beier 1995) faced little choice but to move between cities in search of work, charity, or, as was often the case, opportunities for thievery or petty crime in order to survive. City officials commonly responded by using the sanction of banishment to push them onto other communities. While almost all of the non-capital sentences passed in Amsterdam between 1650 and 1750 involved banishment, most of these were passed on "non-settled petty-criminal vagrants for crimes such as thievery" (Spierenburg 1998, 56 ). A 1612 edict under King Louis XIII ordered all non-native poor of Paris to leave under threat of expulsion (Balch 1893). Beggars and vagabonds typically faced the same fate in late $17^{\text {th }}$ and early $18^{\text {th }}$ century Paris. 
Convicted vagabonds could also expect to be "branded on the right shoulder so that they could be identified if they returned." (Garrioch 2004, 59-60). The Vagabonds Act of 1597 was passed in England under the rule of Elizabeth I, allowing poor transients who refused to reform their "rougish kind of life" to "be banished out of this Realme". In the German city of Ulm, the punishment was employed in the $16^{\text {th }}$ century to discipline migrant labourers who worked as domestic servants and apprentices in Ulm's households and workshops (Coy 2008). Throughout the century, the town council used banishment to deter and punish "idleness" and other violations of town regulations by foreign workers.

Despite its ubiquity, banishment was an ineffective way of dealing with transients and vagabonds. It simply pushed the unwanted people on to other cities or towns, leading them eventually to return. This led large cities to try other responses to vagrants and itinerant people. In Amsterdam, for example, workhouses were established for vagrants and in Paris public works and military conscription were at various times used as alternatives to expulsion. But these alternatives tended to be expensive or inadequate due to the number people involved, and banishment, imperfect as it was, retained its appeal (Spierenburg, 1995, 26; Garrioch 2004; Balch 1893).

At the same time, another a more profound change in banishment was occurring. The most common form of banishment in medieval Europe was expulsion from the town, city, or kingdom. But in the early $17^{\text {th }}$ century, a number of countries began to use expulsion to a particular place overseas, often with an additional requirement of compulsory labour, as punishment. Here was a form of deportatio, but with a twist. The authorities would simultaneously expel the miscreant and exploit their labour.

Galley sentences in the $16^{\text {th }}$ and $17^{\text {th }}$ centuries presaged this change. Until the $16^{\text {th }}$ century galley boats were typically crewed by free men, thereafter, however, life on a galley became a productive alternative to a death sentence for courts in a number of European countries. The ability of the galleys to serve as a routine punishment was limited. The ships could only go out to sea in the calmer months and the galleys were used mostly by sea-bordering states, like those on the Mediterranean. By the eighteenth century, the "size, speed and firepower" of sailing ships had made them redundant altogether (Langbein 2012, 30).

The linkage between exile and labour was most evident in the rise of convict transportation from the $17^{\text {th }}$ century. The transportation of convicts to colonies was used by a range of European states at various times including France, Germany and Austria; Russia's use of exile 
to Siberia from the late 1500 s also had similarities to the practice, particularly once it became widely used in the $19^{\text {th }}$ century. It was in Britain, however, that transportation was most significant. The exile of convicts was first used under James I in 1615 in order to clamp down on perceived misuse of the oath of abjuration (Bleichmar 1999). Only after 1718, however, was transportation used with any regularity when the government enlisted private contractors to transport convicts to the Americas to use as indentured labourers. Over the next sixty years, more than 30,000 felons were transported across the Atlantic primarily to work as labourers, with more than two thirds of them going to Maryland and Virginia.

It was not coincidental that transportation arose in England during a period of colonial expansion. A 1602 commission saw one of the key advantages of transportation as lying in the fact that the convicts would "yield a profitable service to the Commonwealth in parts abroad" (Langbein 2012, 56). But transportation was not simply a vehicle for imperial expansion. A key part of its appeal lay, as in other forms of banishment, in its provision of an alternative to the death penalty. Transportation, as Langbein notes, "gave England a via media between the blood sanctions and the petty sanctions, comparable to the French galley sentence." $(2012,54-$ 55) Indeed, not everyone was satisfied with its putative moderation. In a tract of 1725, Bernard Mandeville decried transportation to the Americas as too "mild": "The criminals have no dread against it, remain as they were themselves, and do no service to others" (de Mandeville 1725). He proposed that convicts instead be sold on to be slaves in North Africa.

Like other types of judicial exile, penal transportation uprooted the offender from his home, community, friends and social world. But it differed from the most ubiquitous forms of historical banishment in a number of ways. Not only was the transported individual sent to a particular place but, as we have noted, the sentence also involved convict labour for a specified period. Furthermore, transported convicts did not lose their membership status and were thus not made civically dead. Even convicts sent to Australia remained subjects of the Realm with the corresponding rights and duties of the status (Hughes 2012). Unsurprisingly, the punishment was enacted with little of the ceremony of rejection that attached to more traditional forms of banishment.

The differences between old style banishment as relegatio and the new exploitative form of deportatio that was transportation was not lost on all miscreants. In one renowned Scottish court case of the early 1800s, two individuals, a Mr Muir and Mr Palmer, unsuccessfully attempted to trade on the differences between the two to challenge their sentence of 
transportation to Australia. Their lawyers claimed that their sentence under a 1703 Act which forbade leasing-making (the uttering of lies about the sovereign) specified that they be "banished" as a punishment. This, their lawyers argued, required simply that they leave the Realm rather than be transported in chains to Australia (Hansard 1794-1795: 267-280). They lost the case and were duly transported. The authorities were loath to accept a distinction between the banishment and transportation if it were to undermine expulsion rendering a useful service to the Crown.

\section{$I V$. The political theory of banishment}

Ancient and medieval thinkers did not generally question the legitimacy of banishment as a punishment. This is unsurprising given the importance they attached to the primacy of community in its various shapes and forms, and, particularly in the case of those writing in the Middle Ages, to the practice's theological endorsement. But one might have expected more scrutiny of the practice from thinkers of the Enlightenment, attracted as they were by the individual as a rights-bearing subject. Nonetheless, Enlightenment thinkers generally vindicated the punishment. I mentioned at the outset Beccaria's support for banishment; he was not alone.

The pioneering theorist of International Law, Emmerich de Vattel, for example, wrote that banishment, which he defined as "exile with the mark of infamy annexed" that occurred because of punishment was acceptable as "any right whatsoever may be deprived by way of punishment" (Vattel 1849 [1758], 107). For Immanuel Kant, a dangerous individual could legitimately be expelled to either "the wide world" or, as in transportation, to "a particular country" (Kant 2002, 205). While Hugo Grotius and Samuel Pufendorf drew directly upon the practices of Ancient Greece and Rome to affirm banishment's acceptability. Pufendorf believed that while atheists who kept their beliefs to themselves should "not [be] punishable by the law", public atheists "may lawfully be banished... for the... public safety" (quoted in Benke and Grenda 2010, 315)

Not all agreed. Hobbes bitterly criticised the punishment's utility. Unless a man was deprived of "his land or goods", i.e., things over and above exile, banishment amounted to "merely a change of air." Worse, banishment put an end to an individual's subjection to the state and ended any obligation he had to it; this raised the prospect that a state's enemies are left to roam free and inflict "damage...to the Commonwealth" (Hobbes 1995, chap 28). Cornelius van Bynkershoek, the early $18^{\text {th }}$ century Dutch jurist, described the practice of banishment from as 
"useless and contrary to the dictates of kinship" because it leads to a mere recycling of criminals between jurisdictions whereby cities "expel their criminals and receive as many" or more "in return". It would, he argues, "be better to confine such criminals in workhouses than to impose them upon others because we fear them" (Bynkershoek 1930, Book II, Chap 17).

These criticisms remained exceptional throughout the $17^{\text {th }}$ and $18^{\text {th }}$ century. Most early liberal theorists, Beccaria notwithstanding, accepted that the state had the right to use capital punishment for a wide range of transgressions of the law; and if physical death could be an acceptable sanction for malefactors, why not civic death? Moreover, even if, like Beccaria, one viewed capital punishment as problematical, the question remained of how to punish and, more specifically, rid society, of dangerous individuals in communities that did not have the capacity or resources to use imprisonment for long periods.

Furthermore, for seventeenth and eighteenth century theorists who viewed society and government through the metaphor of the social contract, banishment seemed particularly appropriate. The idea of the state as a compact between free and rational individuals who join together create a society of laws to forward their individual and collective goals provided a new way of legitimating punishment through implicit or idealised individual consent. Banishment as a punishment seemed highly consistent with this social contract ideal. For if serious crime was conceptualised as a violation of the mutual obligations people have to each other, an obvious response to the criminal was to deprive him of the benefits of the society through physical expulsion from the contract. In the forbidding language of Rousseau, the malefactor - the individual who has attacked social rights - has effectively declared "war" upon the social compact, making "the preservation of the state" inconsistent with his own existence. He therefore "must be removed [from society] by exile as a violator of the compact, or by death as a public enemy" (Rousseau 1913, Book II, chap.5).

For Kant, the state's right to banish a corollary of the individual's right to emigrate from society and exit the social contract. Hence Kant asserts that a state cannot prevent an individual from emigrating "for the state cannot retain him as if her was its property" (2002, chap 50), just before he defends the state' right to banish those who commit serious crimes. Emigration and expulsion were even more explicitly linked in Vattel's discussion of the responsibilities of states. Discussing the varied ways in which an individual can rightfully "quit" a society, Vattel argues that "If the body of the society, or he who represents it absolutely, fails to discharge the obligation towards the citizen, the latter may withdraw himself. For if one of the contracting 
parties does not observe his engagements, the other is no longer obliged to fulfil his". "It is", Vattel states, "on the same principle also that a society may expel a member who violates its laws" (Vattel 1849 [1758], 105).

Despite the fact that most enlightenment theorists did not challenge the acceptability of banishment per se, they did express, particularly from the eighteenth century, concerns about the way in which the punishment was used. Beccaria cautioned that a society need stronger reasons to justify banishing a citizen than a stranger, seemingly because of losses hardships for the individual concerned were much greater $(1995,57)$. He also argued powerfully against the state's right to seize the assets of a banished individual as a part of his punishment. This practice, Beccaria claimed, unjustly left the family of the malefactor in abject destitution. If "death and banishment" really "are identical in the eyes of the body politic", the property of the banished individual should be inherited by his family as in the case of physical death (1995, $58)$.

Other enlightenment liberals expressed concerns that the power could lead to arbitrary and politically-motivated expulsions. Writing in response to the hostile treatment proposed for British Loyalists after the American Revolution in 1784, Alexander Hamilton warned his compatriots against the "dangerous" doctrine of "disqualification, disfranchisement and banishment by acts of legislature" as a way of ridding the country of those who battled against independence. If, he argued, the legislature can "banish at discretion all those whom particular circumstances render obnoxious, without hearing or trial, no man can be safe, nor know when he may be the innocent victim of a prevailing faction" (Hamilton 1784).

Several decades later, the French liberal, Benjamin Constant, declared that "all political exile is a political abuse" $(1988,322)$. In his famous 1820 essay, "On the Liberty of the Ancients Compared to that of the Moderns", Constant used the banishment as a symbol of the shift from old concept of (participatory) liberty of the ancients to the modern conception of liberty as freedom from state interference. The attempt by Jacobins to revive the practice of ostracism flew in the face of the fact that in modern society "individuals have rights which society must respect" $(1988,321)$. Banishment cruelly tore "the citizen from his country, the owner away from his possessions, the merchant away from his trade, the husband from his wife, the father from his children... and the old man from his accustomed way of life" $(1988,322)$. In modern society, Constant argued that "all exile pronounced by assembly for alleged reasons for public safety is a crime which the assembly commits against public safety" $(1988,322)$. Yet for all 
his passion, Constant's concerns about banishment, like those of Hamilton, were essentially procedural. No one has the right to exile a citizen, Constant suggested, unless he is "condemned by a regular tribunal, according to a formal law which attaches the penalty of exile to the action of which he is guilty" (1988, 321-322). Only the arbitrary, politically motivated banishment of citizens is an affront to modern liberty.

\section{The banishment of banishment}

The criticisms of banishment by Enlightenment liberals were, despite their mildness, a sign of a more general scepticism of the practice. By the late $18^{\text {th }}$ century a number of changes had come into place that would, over the course of the $19^{\text {th }}$ century, interact to make the expulsion of citizens by states practically difficult and normatively unacceptable.

The first of these changes can be gleaned in Voltaire's criticism of banishment in his Encyclopedia as equivalent to "throwing into our neighbour's field the stones that incommode us in our own" $(1843,192)$. The statement captured banishment's essential irrationality-the fact that the practice did little more than recycle undesirables between neighbours. This was not a novel idea. As early as the 1600 s, magistrates in Leiden had recognised that "we [the people of Leiden] banish people upon each other's necks" (Spierenberg 1998, 355). As I have shown, there were even attempts to get around this "beggar they neighbour" response in the $17^{\text {th }}$ and the early $18^{\text {th }}$ century through workhouses and conscription. But these attempts failed both due to the expense of maintaining such places of detention and the difficulties of getting cities to cooperate.

In the late $18^{\text {th }}$ century, however, the administration of governance in European societies became more centralised as the modern bureaucratic state began to develop. Increasingly, across Europe, "competencies previously the task of local bodies, including policing, taxation ...censuses" and justice began to assumed by national governments and operated through central bureaucracies (Buzan \& Lawson 2013, 627). This new context provided states with both the motivation (the instantiation of national good over and above that of specific local communities) and the power to regulate and harmonise the criminal justice practices of local regimes (Kingston 2005, 33). Consequently, by the late $18^{\text {th }}$ century, banishment between cities (relegatio) began to disappear, replaced either by imprisonment or convict transportation overseas (deportatio) to colonial possessions. Countries without colonies were forced to devise more ingenious means to expel the unwanted. In the 1830s, Canadian authorities arranged with British authorities for the transportation of around 100 individuals guilty of involvement in the 
1837 revolt in Upper Canada to be transported to Van Dieman's Land in Australia (Weaver 1995, 60-61). A number of German states, including Hanover, achieved a similar end by offering early release to convicts if they emigrated to the United States, a practice that continued until the 1850s (Evans 1998, 68).

While transportation overseas had become the main option for expelling miscreants by the early 1800s, the precariousness of this practice was made evident in a second key event: Benjamin Franklin's acerbic call in 1754 for Americans to rise up against Britain's dumping of transported convicts by sending rattlesnakes back to England. Franklin's rebuke was an early signal that the rise of nationalism and ideas of popular sovereignty were hardening societies into more clearly defined membership units, reinforcing distinctions between outsiders and insiders and making territorial boundaries politically and symbolically important. Over late eighteenth and early nineteenth centuries, as John Torpey $(2018,11)$ has shown, European states increasingly came to use technology and surveillance, culminating in the development of the passport, to "embrace their own subjects and to exclude unwanted others". At the same time, popular sovereignty (and the expansion of the franchise over the nineteenth century) led members (citizens) to make increasing demands on their governments for preferential treatment in the distribution of economic and social goods, like employment and welfare.

The effect of nationalism and popular sovereignty in destination colonies meant that it was harder for European states to treat these countries simply as dumping grounds for its offenders. Transportation to America would end with independence from Britain in 1776, as Benjamin Franklin had hoped. By the 1840s, anti-transportation campaigns had emerged in New South Wales attracting settlers with the claim that it was "incompatible with our existence as a free colony, desiring self-government to be the receptacle of another country's felons" (Hughes 2012, 555). Similar campaigns spread over the next twenty years to other Australian colonies and by the end of the 1860 s, exiling convicts to Australia had ceased altogether. German attempts to set up penal colonies in the 1890s in possessions in Africa and New Guinea were also scuppered in part by the objections of (and concerns for) free settlers (Evans 1998, 80). In an 1819 British parliamentary debate on restoring banishment, one politician asked rhetorically, "Could it be supposed that any one of ...[the] Sovereigns [of Europe] would suffer the subject of the other to remain in his dominions ...if he was known to have been an outcast from that country?" (HC Deb 23 Dec 1819 cc 1560). 
The effect of nationalism in reorienting the relationship between the state and its citizens also affected the motivations of banishing states. The claim that each state was a particular and unique people made it more difficult for states to engage in the absolution of responsibility for a citizen central to banishment. This attitude was captured in 1826 by the authorities in the small Franconian principality of Saxe-Coburg-Gotha when they rejected the transportation practices of other German provinces: "for... [a government] to allow the subjects whom God has entrusted to it alone to be torn away from the Fatherland and thus from its own responsibility, and to be transported into a land under a far distant heaven, thus ridding itself of them completely...can hardly be justified" (Evans 1998, 57).

As the citizen became more politically and bureaucratically important in the nineteenth century, the category of the "alien" or "foreigner" assumed greater significance. The demands citizens now placed on the state to provide employment, regulation and services multiplied the ways in which their interests might come into conflict with those of resident foreigners. Aliens might be competitors for jobs and other publicly distributed goods, such as schooling and housing or poor relief (see Caestecker 1998). More generally, at a time when states were building and consolidating national identities, the foreigner (at home or abroad) could serve as the national community's Other, providing a distinctive set of characteristics against which the national community could define itself (e.g., hard-working rather than lazy; Protestant rather than Catholic, self-sacrificing rather than greedy; Christian rather than Jewish) or simply as threat (Caestaker 1998). As Freud noted, "it is always possible to bind together a considerable number of people in love, so long as there are other people left over to receive the manifestations of their aggressiveness" (quoted in Garber 1998, 70).

Thus while nationalism and popular sovereignty led states and citizens into a tighter embrace, they also multiplied the reasons why states might want to spurn foreigners, particularly those adjudged dangerous or burdensome. Even this desire to discard the foreigner served further to entrench the protection of the citizen from banishment. For the state's right to expel (deport) aliens practically required a correlative duty on the part of other states to accept their own nationals back. These duties and obligations began to congeal into international practice during the $19^{\text {th }}$ century when a growing number of international treaties began to include duties to accept the return of nationals (Coleman, 2008 chap 1). Hence, as Torpey notes more generally, "the authority to regulate movement came to be primarily a property of the international community as a whole" (Torpey 2000, 9). 
A final important development was on display in 1830 observation by the English utilitarian and social reformer, Jeremy Bentham. In a chapter entitled "On Transportation", Bentham launched a scathing critique of the English practice of transporting convicts to New South Wales. Transportation, he argued, made justice a "lottery" rather than a matter of "constancy and precision" because the suffering it imposed on individuals depended on luck (e.g., whether one's ship survived the voyage, the individual escaping disease, or whether one was attacked by "savages"). Furthermore, those convicts who reached Australia were not "improved" by penal transportation but rather became worse "the longer they are subjected" to it (Bentham 1830 , Book V, chapter 2). For Bentham, transportation was vastly inferior to incarceration in a penitentiary as a punishment. When run along the lines of his ideal of the panopticon, the penitentiary provided regular and predictable inspection, surveillance, and routinisation of convict life.

Bentham's criticisms encapsulated two considerations that were beginning to influence the nature of punishment across Europe and North America in the early 1800s. First, that punishment should be consistent, measured and equitable - the same for each and every individual subject to it. This idea befitted an age of democratic sentiments and equal citizenship in England. But it was consistent also with the new centralized bureaucratic state committed to formally equal treatment and controlled by "officials selected according to their expertise, not social status, and in the form of impartial rules" (Willis 2005, 200). In this context, penal transportation increasingly appeared arbitrary, and not only because, as Bentham noted, its consequences varied wildly from individual to individual. In the convict assignment system prevalent in the colonies, the individual was placed under the arbitrary control of private individuals to work on farms and in other parts of society for free settlers. For some sections of the public in Britain this uncomfortably evoked the evils of recently abolished slavery (Willis 2005). The penitentiary, by contrast, offered a more "equitable" and less arbitrary form of punishment", one that administered justice under the watchful eye of a responsive national government (Willis 2005, 199).

On the other hand, Bentham's concern about transportation's failure to "improve" the convict reflected a growing view that the punishment's purpose was to reform. Banishment was part of a worldview that saw the malefactor as putrid limb on the body of society, one that needed to be amputated to prevent the disease from spreading. By expelling the individual, society was protected. In the view of liberal reformers from the late $18^{\text {th }}$ century, by contrast, the malefactor could be improved (healed) and once again made to work in harmony with the rest of society. 
Of course, the contrast was never quite this simple. Temporary banishment had always allowed for the possibility of reintegration after a period of exile. But the penitentiary was widely believed to be more congruent with a reformative ideal. Bentham, for example, saw the surveillance, regimentation, and education the prison provided as "a mill for grinding rogues honest, and idle men industrious" $(2017,242)$. This sanguine view also found support on the continent. In German provinces the penitentiary was seen in the early 1800 s as encouraging the virtues of "order, industry, and cleanliness" amongst inmates (Evans 1998, 63). Moreover, by isolating the miscreant, the prison forced him "to turn inwards...contemplate his soul and repent his crimes" (Evans 1998, 63).

One might argue that imprisonment did not really replace banishment; it simply turned it inwards. The Duke of Kent's response to his sentence of exile in King Lear is that "Freedom lives hence, and banishment is here" (Act 1, scene 1). It is true that modern prison sentences served many of the functions previously filled by banishment. Imprisonment withdrew the offender from society, incapacitating him and preventing spirals of retaliation and revenge. It also deprived the individual of key civic rights, including the right to work, to live with one's family, to move freely, and (often) to vote in elections in a way that seems analogous to loss of citizenship rights associated with banishment.

Yet a key feature--perhaps the key feature--of banishment was the community's washing its hands of the offender. Physical expulsion symbolized an act of disowning (the opposite, perhaps, of Torpey's “embrace”), ending any relationship of responsibility between the society and the malefactor. Imprisonment, on the other hand, was quite different. It involved the state taking on complete responsibility for one of its members. The prisoner was fed, sheltered, and perhaps even reformed by the state, often at considerable cost. The prisoner's loss of liberty created a situation of unique dependence on the state. While the banished individual became a foreigner to the village, city or state; the incarcerated prisoner became, perhaps to the fullest degree possible, the state's subject. In the light of this difference, convict transportation might best be seen as a transitionary arrangement between traditional banishment and the prison: the individual still faced exile but he or she remained the state's responsibility (albeit a responsibility often negligently discharged).

From the early 1800 s the penitentiary made great strides in replacing alternative punishments, not least banishment. Evans notes that with the construction and amendment of a range of prisons across Germany along the lines of Pentonville, calls for the deportation of incorrigible 
"no longer seems so urgent as it had at the beginning of the century" (Evans 1998). The province of Ontario in Canada which had in the early 1800s amended its criminal codes to allow for offenders to be banished (sent across the border to the US), effectively ended the practice when the Kingston Penitentiary was built in 1835 (Murray 2003, 185). In France, though the punishment had moved up and down in popularity since the Revolution, it was in decline by the mid-nineteenth century with "only five sentences of banishment were declared in the period from 1831 to 1850 (on average one every four years)" (Kingston 2005, 34). These sentences were often transformed into a period in prison. In Britain, the prison gained ground even in the latter half of the eighteenth century, "accounting for at least two-thirds of criminal sentences by the end of the century", despite it being exceedingly rare at the beginning of the century (Spierenburg 1995, 76). Its dominance became undeniable by the mid-1800s.

Banishment as a formal punishment did not die a quick death. Britain ended transportation of convicts to Australia only in 1864, and then mostly because of pressure from colonists in Western Australia. In the early twentieth century, some Russian peasant villages still had the power to banish anti-social individuals through a vote of two-thirds of the village assembly (Frank 1999, 237). Sentences of banishment out of the province were still handed down in Canada's Gore District in the early 1850s. The German states employed, with greater or lesser degrees of success, banishment in various forms throughout the $19^{\text {th }}$ century including, as noted, royal pardons to felons who agreed to emigrate to the United States (Evans 1998 65-67). The French abolished banishment in the aftermath of the Revolution of 1789 only to revive the punishment after 1810 under the new Napoleonic code, though this time primarily to deal with threats to the political order rather than common criminals. However, banishment from the state was used on dwindling numbers of people after its reintroduction and was effectively replaced by a form of transportation to French Guinea and the infamous Devil's Island, a penal colony that closed completely only in 1953.

\section{Conclusion}

The account I have given here suggests that the punishment of "disowning" citizens through expulsion receded not because banishment came to be considered cruel or antiquated, but because it was increasingly at odds with the sovereign rights of other states (in particular, the reciprocal right to control entrance and immigration) and with changes in the way membership in the state was conceptualised. These changes were reinforced during the $20^{\text {th }}$ century with the spread of the international system as a result of the end of colonialism (which effectively 
eliminated the existence of spaces where unwanted citizens could be dumped), and with the emergence, somewhat after the fact, of international and domestic human rights norms, which limited the ability of states to make people stateless and prohibited arbitrary exile. ${ }^{3}$

As a result of these developments, the act of "disowning" and the practice of expulsion have become formally separate in contemporary states. Modern deportation power is used solely on the "non-citizen" and thus limited to those the state does not "own". Equally, it is restricted to those "owned" by another state by virtue of the individual's possession of that state's nationality. Deportees are thus returned or repatriated to their country of membership rather than banished or exiled, and this act is justified not as a punishment but as a consequence of lack of membership. Of course, for many of the individuals subjected to the hardships of deportation power - in particular, those that have been resident for most of their lives in the state they are forced to leave - the difference between this kind of coerced legal "return" and banishment is often little more than a legal nicety (Kanstroom 2007).

By contrast, denationalization, the closest contemporary analogue to "disownment", is, in its legal construction, distinct from expulsion. Many states have recently revived their powers to strip their unwanted citizens of nationality, making them no longer members. But the act of expulsion is another process altogether, subject to the protections and procedures applicable to non-citizens facing deportation and thus separate from formal processes of punishment. Above all, the state can only expel - and thus genuinely cut ties to - an individual if she is "owned" elsewhere. The nature of this process distinguishes denationalization from banishment as it was most commonly practiced historically. Banishment combined the loss of membership and expulsion into one act, or, more precisely, one punishment. The expelling society needed only to get the individual out, not make her someone else's formal responsibility. The modern twostep process reflects the fact that while many states have authority to define who will acquire citizenship and, with much greater restrictions, who can be deprived of it, they lack the authority unilaterally to expel their own citizens as a punishment or otherwise.

Again, this distinction may appear otiose from the point of view of the denationalized person who is vulnerable to deportation. But it creates substantial practical and legal constraints on

\footnotetext{
${ }^{3}$ After WWII, a number of international treaties were signed including the Universal Declaration on Human Rights (1948), the International Covenant on Civil and Political Rights (1966), and the Convention on the Reduction of Statelessness (1961), that legally and morally enshrined a degree of protection for citizens against expulsion and reinforce the impermissibility of banishment. I consider these developments in Gibney 2020.
} 
the lawful ability of states to get rid of their own citizens, restricting the exercise of any such power solely to citizens who have an alternative nationality. Further constraints emerge from domestic and international norms about the security of citizenship. Banishment, therefore, may be "back from exile", but it is in a form well and truly tamed by the modern state system.

\section{References}

Allen, Danielle. 2000. The World of Prometheus: The Politics of Punishing in Democratic Athens. Princeton: Princeton University Press.

Allen, Danielle. 2003. "Punishment in Ancient Athens," in Demos: Classical Athenian Democracy, The Stoa. Online at: http://www.stoa.org/projects/demos/punishment.pdf

Andrews, Richard. 1994. Law, Magistracy, and Crime in Old Regime Paris, 1735-1789: Volume 1, The System of Criminal Justice. Vol. 1. Cambridge: Cambridge University Press

Beier, A. Lee. 1985. Masterless Men: The Vagrancy Problem in England 1560-1640. Routledge.

Bartlett, C. Nathan, and Laura Ford Cruz. 2007. "Let The Punishment Fit The Crime: The Social Miracle And Criminal Sentencing In Early Modern Leiden." In Politics and Reformations: Communities, Polities, Nations, and Empires, Brill.

Bauman, Richard A. 2002. Crime and punishment in Ancient Rome. Routledge.

Becarria, Cesar. 1995. Of Crimes and Punishments, edited by R. Bellamy, Cambridge: Cambridge University Press.

Benke, C. and Grenda, C.S. 2010. The First Prejudice: Religious Tolerance and Intolerance in Early America, Philadelphia, PA: University of Pennsylvania Press

Bentham, Jeremy, 1830, The Rationale of Punishment, London: Robert Heward

Bleichmar, Javier, 1999, "Deportation as Punishment: A Historical Analysis of the British Practice of Banishment and Its Impact on Modern Constitutional Law." Georgetown. Immigration Law Journal, 14, pp. 115-163

Braginton, Mary. 1944."Exile under the Roman emperors", The Classical Journal 39, no. 7, 391-

407.

Buzan, Barry and George Lawson. 2013, "The Global Transformation: The Nineteenth Century and the Making of Modern International Relations", International Studies Quarterly 57, 3, pp. 620-634.

van Bynkershoek, C. 1930. Quaestionum juris publici libri duo, vol I, translated into English by T. Frank, Oxford: Clarendon.

Caestecker, Frank. 1998. "The changing modalities of regulation in international migration within continental Europe, 1870-1940." In Regulation of Migration: International Experiences, edited by A. Bocker. Aksant. 
Cartledge, Paul, 2006, "Ostracism: selection and de-selection in ancient Greece", online at http://www.historyandpolicy.org/policy-papers/papers/ostracism-selection-and-de-selectionin-ancient-greece

Claassen, J., 1992. “Cicero's Banishment: tempora et mores". Acta Classica, 35, pp.19-47.

Cohen, Sarah. 2008. "Augustus, Julia and the development of exile ad insulam." The Classical Quarterly 58, 1, pp. 206-217.

Constant, Benjamin. 1988. Constant: Political Writings, edited by B. Fontana, Cambridge: Cambridge University Press.

Coy, Jason. 2008. Strangers and Misfits: Banishment, Social Control, and Authority in Early Modern Germany. Brill.

Coy, J.P. 2008. "Beggars at the gates: Banishment and exclusion in sixteenth-century Ulm." The Sixteenth Century Journal, 39, 3. pp. 619-638.

Dean, Trevor. 2014. Crime in Medieval Europe: 1200-1550. Routledge.

Dorin, R.W. 2015, "Banishing Usury: The Expulsion of Foreign Moneylenders in Medieval Europe, 1200-1450." PhD dissertation, History Department, Harvard University

Eriksson, Torsten. 1976. The Reformers: An Historical Survey of Pioneer Experiments in the Treatment of Criminals. Greenwood.

Evans, R.J. 1996. Rituals of Retribution: Capital Punishment in Germany, 1600-1987. Oxford: Oxford University Press.

Evans, R J. 1998. Tales from the German underworld: Crime and Punishment in the Nineteenth Century. New Haven: Yale University Press.

Fahrmeir, Andreas, 2000. Citizens and Aliens: Foreigners and the Law in Britain and the German States, 1789-1870, Oxford: Berghahn.

Forsdyke, Sara. 2009. Exile, Ostracism, and Democracy. Princeton: Princeton University Press.

Friedland, Paul. 2012. Seeing Justice Done: The Age of Spectacular Capital Punishment in France. Oxford: Oxford University Press

Garber, Marjorie 1998. Symptoms of Culture. Psychology Press.

Garrioch, David. 2004. The Making of Revolutionary Paris. University of California Press.

Geremek, Bronislaw. 2006. The Margins of Society in Late Medieval Paris. Cambridge: Cambridge University Press

Gibney, M. J. 2013. 'Should citizenship be conditional? The ethics of denationalization'. The Journal of Politics, 75(3), 646-658

Gibney, M.J. 2020, Denationalizaton and the Liberal State, Cambridge: Cambridge University Press.

Gray, Benjamin. 2011. "From Exile of Citizens to Deportation of Non-Citizens: Ancient Greece as a Mirror to Illuminate a Modern Transition." Citizenship Studies 15, 5, pp 565-582. 
Grebe, Sabine. "Why did Ovid Associate his Exile with a Living Death?." Classical world (2010): 491-509.

Hamilton, Alexander. 1784. "A Letter from Phocion to the Considerate Citizens of New York", [1-27 January 1784]," Founders Online, National Archives. https://founders.archives.gov/documents/Hamilton/01-03-02-0314.

Hobbes, Thomas. 1996. Leviathan, R. Tuck, editor, Cambridge: Cambridge University Press

Hillner, J. D. 2013. "Confined Exiles: An Aspect of the Late Antique Prison

System. Millennium: Jahrbuch zu Kultur und Geschichte des ersten Jahrtausends n. Chr., 10, 1, pp. 385-433.

Holborn, Hajo. 1982. A History of Modern Germany: The Reformation. Vol. 1. Princeton: Princeton University Press

Hughes, Robert 2012, The Fatal Shore, New York: Vintage

Jordan, William Chester. From England to France: Felony and Exile in the High Middle Ages. Princeton: Princeton University Press, 2015.

Kanstroom, D., 2007. Deportation Nation: Outsiders in American History, Cambridge: Harvard University Press.

Kant, Immanuel. 2002. The Philosophy of Law, trans by W. Hastie, Clark: Law Book Exchange

Kingston, Rebecca. 2005. "The Unmaking of Citizens: Banishment and the Modern Citizenship Regime in France." Citizenship Studies 9, 1, pp. 23-40.

Langbein, J.H. 2012. Torture and the Law of Proof: Europe and England in the Ancien Régime. Chicago: University of Chicago Press

Lenard, Patti. 2019. "Punishment or Banishment", Centre for International Policy Studies, 22 February. Online at: https://www.cips-cepi.ca/2019/02/22/we-must-punish-our-ownterrorists-not-revoke-their-citizenship/

Macklin. A. 2015. 'Introduction' in Macklin, A. and Baubock, R. eds., The Return of Banishment, Florence: EUI Working Papers.

Mantu, S. 2015. Contingent Citizenship: The Law and Practice of Citizenship Deprivation in International, European and National Perspectives. Brill.

de Mandeville, Bernard 1964.An Enquiry Into the Causes of the Frequent Executions Tyburn:(1725). Univ. of Calif.

Margolf, D.C. 2017. Religion and Royal Justice in Early Modern France: The Paris Chambre de l'Edit, 1598-1665. Truman State University Press.

Nicholas, David. 2014. The Later Medieval City: 1300-1500. Routledge.

Perkins, Judith. 2013. "The Spectacle of "Bare Life" in Martial's Liber Spectaculorum and Martyr Discourse." Roman Literature, Gender and Reception: Domina Illustris, pp:179-95.

Rousseau, J-J. 1913. Social Contract \& Discourses. New York: E. P. Dutton \& Co

Robinson, O.F. 2007. Penal Practice and Penal Policy in Ancient Rome. Routledge, 2007. 
Sartore, Melissa. 2013. Outlawry, Governance, and Law in Medieval England. Peter Lang

Spierenburg, P.C. 1998. "Close To The Edge: Criminals and Marginals in Dutch Cities”, Eighteenth-Century Studies, Volume 31, 3, 1998, pp. 355-359

Spierenburg, P.C. 1995. "The body and the State" in The Oxford History of the Prison, edited by N. Morris \& D. Rothman. Oxford: Oxford University Press.

Tarlow, Sarah, and Emma Battell Lowman. 2018 "The Power of the Criminal Corpse in the Medieval World." In Harnessing the Power of the Criminal Corpse,Palgrave/Macmillan,

Torpey, J.C. 2000. The Invention of the Passport: Surveillance, Citizenship and the State. Cambridge: Cambridge University Press.

de Vattel, E. 1844. The Law of Nations, translated by J. Chitty, T. and J.W. Johnson, Philadelphia:

Voltaire. 1843. A Philosophical Dictionary: Volume II, London, W. Dugdale.

Walters, William. 2002. "Deportation, expulsion, and the international police of aliens", Citizenship Studies, 6(3), pp.265-292.

Washburn, Daniel. 2012. Banishment in the Later Roman Empire, 284-476 CE. Routledge

Willis, James J. 2005. "Transportation versus Imprisonment in Eighteenth-and NineteenthCentury Britain: Penal Power, Liberty, and the State," Law \& Society Review, 39, 1, pp. 171210 .

Wise, C. 2014. Banished to the Black Sea: Ovid's Poetic Transformations in Tristia 1.1. Doctoral Dissertation, Department of Classics, Georgetown University, Washington DC.

Weaver, J.C. 1995. Crimes, Constables, and Courts: Order and Transgression in a Canadian City, 1816-1970. McGill-Queen's Press-MQUP.

Wolfgang, M.E. 1953. "Political Crimes and Punishments in Renaissance Florence," Journal of Criminal Law, Criminology \& Police Science, 44, pp 555-581. 